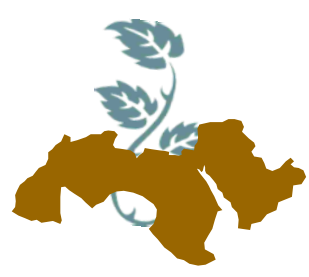

\title{
EVALUATION OF PAN BREAD PRODUCED BY USING BAKER'S YEAST DERIVED FROM DISTILLED BIOMASS
}

\author{
$[141]$ \\ Sarah E.A. Soliman ${ }^{1}$, Yousif ${ }^{2}$ E.I., Abdel Fattah ${ }^{2}$ A.A. and Shams El-Din ${ }^{1}$ M.H. \\ 1- Food Technology Dept., National Research Centre, Dokki, Giza, Egypt \\ 2- Food Science Dept., Fac. of Agric., Ain Shams Univ., P.O. Box 68 Hadayek Shoubra 11241, \\ Cairo, Egypt \\ * E-mail address of Corresponding author: abdeo1978@agr.asu.edu.eg
}

Keywords: Distilled yeast, Baker's yeast, Fermenting power, Pan bread, Physical properties, Color, Freshness

\begin{abstract}
The chemical composition, physical properties, sensory evaluation, texture properties and color properties of pan bread produced by using $S$. cerevisiae (F514) treatment 1, S. cerevisiae (F707) treatment 2 and a mix of $S$. cerevisiae (F514) and commercial baker's yeast with 1:1 ratio treatment 3 were studied. Results showed significant differences between pan bread samples in ash and dry matter contents. Treatment 3 samples recorded the highest values of volume and specific volume $\left(560 \mathrm{~cm}^{3}\right.$ and 4.06$)$ followed by treatment2 (447.5 $\mathrm{cm}^{3}$ and 3.20), and then treatment $1\left(380 \mathrm{~cm}^{3}\right.$ and 2.64) respectively. Treatment 3 samples recorded the highest scores in crumb texture, taste characteristics and total acceptability (14.13, 18.5 and 92; respectively) followed by treatment 2 samples (13.25, 17.5 and 87.63; respectively), whereas minimum scores were given to treatment 1 samples (12.25, 16.25 and 81.13; respectively). There was a significant gradual decrease in alkaline water retention, as well staling rate increased in all samples during storage at room temperature $25 \pm$ $2^{\circ} \mathrm{C}$ for $72 \mathrm{~h}$. The alkaline water retention capacity after $72 \mathrm{~h}$ in treatment 3 samples was $148.61 \%$ compared with 122.36 and $121.53 \%$ for treatment 1 and treatment 2 samples respectively. The crust of pan bread sample produced by treatment 2 recorded the highest value of the yellowness followed by treatment 1 and treatment 3 . In the crumb, the lowest value of $\left(\mathrm{L}^{*}\right)$ was recorded by treatment
\end{abstract}

1samples and the highest value by treatment 2 followed by treatment 3 samples. Treatment 3 pan bread samples had the lowest value of hardness $(6.685 \mathrm{~N})$ followed by treatment $2(15.02 \mathrm{~N})$ and treatment $1(16.86 \mathrm{~N})$. Treatment 3 samples had the lowest values of chewiness $(4.97 \mathrm{~J})$ and the highest values of cohesiveness (19.68 mm). Meanwhile, treatment 1 samples had the lowest values of springiness $(0.69 \mathrm{~mm})$.

\section{INTRODUCTION}

Baker's yeast is used for bread fermentation throughout the world, is very important for the bread quality. Different commercial baker's yeasts are each highly selected strains of the species Saccharomyces cerevisiae. The fermentative activity of baker's yeast is essential not only for the rising action of the dough by production of $\mathrm{CO}_{2}$, but also in production of the wide range of aroma compounds identified in bread (Schieberle and Grosch, 1991; Frasse et al 1992 and Birch et al 2013).

The most common food grade yeast is Saccharomyces cerevisiae, also known as baker's yeast, which is used worldwide for the production of bread and baking products. Three factories follow The Egyptian Sugar and Integrated Industries Company (ESIIC) are devoted for the production of ethanol alcohol for industrial purposes using molasses through alcoholic fermentation processes. This fermentation is carried out by ethanol-tolerant strains of Saccharomyces cerevisiae i.e. similar to those strains employed in baker's yeast production. During ethanol production by fermentation substantial amount of yeast cells that are physio- 
logically exhausted and alcohol injured or damaged are produced as a by-product of the fermentation processes, this distilled yeast used later as fodder yeast. The annual production of fodder yeast is 600 tones according the official website of the company.

The yeast employed in bread making must have $72 \%$ moisture or less, viable cells $9 \times 109$ fresh yeast, ash content not exceeding $8 \%$. Protein content greatly influence the fermentation ability of yeast and the baking quality of bakery products. Higher protein content is known to imply increased enzyme activities and shelf life. It's known that yeast strain has a great effect on the rate of fermentation and gas production. Different biochemical changes caused by yeast activity during dough fermentation affect the characteristics of the final bread loaves (Faheid et al 1997).

Successive washing of distilled yeast cells resulted in increasing its fermenting power and this result could be referred to lowering the ethanol concentration presumably accumulated in the yeast during ethanol fermentation (Fatma, 2012). Nitrogen source is one of the important factors during fermentation that effects on yeast biomass yield and fermentation potency (Bothast and Schlicher, 2005).

The aim of this work was to use this improved distilled yeast strain that have simulate properties of traditional baker's yeast and to be applied in baking purposes to fulfill the gap between local production baker's yeast and actual requirements of the local market.

\section{MATERIALS AND METHODS}

\section{Microorganisms}

Saccharomyces cerevisiae F-514 strain as a distilled yeast (DY) which is used in ethanol alcohol production from molasses and another strain from the same specie; $S$. cerevisiae F-707 as a baker's yeast (BY) were obtained from The Egyptian sugar and integrated Industries Company Hawamdia, Giza- Egypt. Commercial baker's yeast in compressed form was obtained from the local market during 2017.

\section{Sugar cane molasses}

Sugar cane molasses $(75 \%$ dry matter, $48-56 \%$ total sugars, $46-52 \%$ fermentable sugars and $2-3 \%$ nitrogenous compounds) was obtained from The Egyptian Sugar and Integrated Industries Company Hawamdia, Giza- Egypt.

\section{Wheat flour $72 \%$}

Wheat flour (72\%) was purchased during 2017 from Five Star Flour Mills Company, Attaqa Industrial Zone, Egypt. Flour was stored at $5^{\circ} \mathrm{C}$ in the refrigerator for 2 months before use.

\section{Salt and shortening}

Salt and shortening were obtained from the local market during 2017. Salt was kept in a dry good aerated place. Shortening was used within the day was purchased.

\section{Chemicals}

Chemicals used in this study were analytical grade, were obtained from obtained from Merck kGaA 64271 Darmstadt, Germany, Fluka Chemie AG CH-9470 Buchs and Elgomhouria company trading chemicals and medical appliances, Cairo, Egypt.

\section{Biomass preparation}

The inoculums of the two yeast strains (S. cerevisiae F-514 and S. cerevisiae F-707) were prepared using conical flasks of $500 \mathrm{ml}$ capacity contained medium of Yeast dextrose broth $(\mathrm{g} / \mathrm{l}): 3 \mathrm{~g}$ yeast extract, $5 \mathrm{~g}$ peptone, $3 \mathrm{~g}$ malt extract and $10 \mathrm{~g}$ glucose (Taylor and Marsh, 1984). After sterilization by autoclave at $121^{\circ} \mathrm{C}$ for $15 \mathrm{~min}$, the cooled flasks were inoculated by a loop of yeast culture and incubated in a rotary shaker $150 \mathrm{rpm}$ adjusted at $34{ }^{\circ} \mathrm{C}$ for $48 \mathrm{hrs}$. The growing yeast starter was used to inoculate the sugar cane molasses medium. This medium was composed of $100 \mathrm{~g}$ molasses (50\% sugar), di ammonium phosphate $2 \mathrm{~g}$, urea $2 \mathrm{~g}$, orthophosphoric acid $0.7 \mathrm{ml}$, magnesium sulfate $0.5 \mathrm{~g}$, zinc sulfate $0.1 \mathrm{~g}$ and biotin $0.015 \mathrm{~g}$ in $1000 \mathrm{ml}$ of distilled water. The $\mathrm{pH}$ was adjusted to 5-5.5 and the medium was sterilized by autoclaving at $121^{\circ} \mathrm{C}$ for 15 minutes, inoculated with $10 \%(\mathrm{v} / \mathrm{v})$ from prepared starter and incubated at $30^{\circ} \mathrm{C}$ for $24 \mathrm{hrs}$. The yeast biomass was separated by centrifugation at $3000 \mathrm{rpm}$ for 10 minutes at $4^{\circ} \mathrm{C}$.

\section{Proximate chemical analysis}

Moisture, protein (total nitrogen X 5.71), ash, crude fiber and total lipid content of samples were determined according to A.O.A.C. (2012). Total carbohydrates (nitrogen free extract) were calculated by differences. Trehalose was extracted from 

distilled biomass

cells biomass according method described by Trevelyan and Harrison (1956) and determined by anthrone method according to Ludwig and Goldberg (1956).

\section{Fermenting power measurement}

The fermenting power of the two yeast strains was measured in a glass measuring cylinder according to Borzani, (2004).

\section{Processing of pan bread}

Pan bread was prepared according to procedure described by Finney, (1984) as follows: $3.5 \%$ yeast (S. cerevisiae (F514), S. cerevisiae (F707) and a mix of S. cerevisiae (F514) and commercial baker's yeast with 1:1 ratio) and were dissolved in warm water $\left(40^{\circ} \mathrm{C}\right)$ and then added to the dry ingredients $(1.5 \% \mathrm{NaCl}, 3 \%$ sugar and $100 \%$ wheat flour $72 \%$ extract). The shortening (2\%) was added and the mixture was kneaded in a mixing bowl for $4 \mathrm{~min}$ at a low speed then for $2 \mathrm{~min}$ at high speed. The dough was fermented for $45 \mathrm{~min}$ at $30^{\circ} \mathrm{C}$ and $80-85 \%$ relative humidity in a fermentation cabinet. The dough was divided into $150 \mathrm{~g}$ pieces (as pan capacity), molded, placed in the pan and proofed under the same conditions for $1 \mathrm{~h}$. The dough pieces were baked at $240{ }^{\circ} \mathrm{C}$ for $20-25 \mathrm{~min}$ following steaming for $10 \mathrm{~s}$ in an electrical oven (Mondial Formi, Model No: 4T 40/60, Italy). Baked loaves were allowed to $\mathrm{cool}$ at room temperature $\left(25^{\circ} \mathrm{C}\right)$ for $60 \mathrm{~min}$ before measuring its volume, weight and before sensory evaluation, and then packed in polyethylene bags for further analysis.

\section{Physical measurements of pan bread}

Weight, volume and specific volume of pan bread loaves were determined as described in A.A.C.C. (2009). Volume of loaves was measured using rapeseeds displacement method.

\section{Sensory evaluation of pan bread}

Sensory evaluation of pan bread loaves was conducted for the freshly baked breads (after one hour from baking) by 10 semi-trained panelists from the staff aged from 25 to 60 years old from Food Industries Technology, National Research Centre; Egypt. The sensory evaluation was conducted in a laboratory under ambient temperature $\left(25^{\circ} \mathrm{C}\right)$ as described by Kulp et al (1985).

\section{Texture properties of pan bread}

Texture parameters (hardness, springiness, cohesiveness, gumminess and chewiness of pan bread samples were measured objectively by using a texture analyzer TA-CT3 (Brookfield, USA) as adopted by the standard method by A.A.C.C. (2009).

\section{Freshness of pan bread}

Loaves freshness of each packed sample was tested at room temperature $\left(25^{\circ} \mathrm{C}\right)$ during storage for 24,48 and $72 \mathrm{~h}$ by alkaline water retention capacity (AWRC) according to method of A.A.C.C. (2009) Method 56-10.02.

\section{Color measurements of pan bread}

The color of pan bread samples were measured using a spectro-colorimeter (tristimulus color machine) with CIE lab color scale (Hunter, Lab Scan XE, Reston VA.) calibrated with a white standard tile of Hunter Lab. color standard (LXNO. 16379): $X=77.26, Y=81.94$ and $Z=88.14$ using cofield's equation (Hunter, 1975).

\section{Statistical Analysis}

Data were expressed as the mean values of three replicates. Analysis was assessed using the Statistical Analysis System software System for Windows (SAS, 2008). The significant difference between the mean values were determined by using the analysis of variance (ANOVA) and Duncan's multiple range test was conducted at a significance level of $95 \%(P \leq \mathbf{0 . 0 5})$.

\section{RESULTS AND DISCUSSION}

\section{Proximate chemical composition of distilled yeast and baker's yeast strains}

Results in Table (1) revealed significant differences between the two strains in moisture, dry matter, protein, ash, fat, total carbohydrates (free nitrogen extract) and trehalose contents. The content of dry matter in S. cerevisiae (F707) was higher than in S. cerevisiae (F514). Protein, fat and trehalose contents in $S$. cerevisiae (F707) were higher than in $S$. cerevisiae (F514). Meanwhile, ash content in $S$. cerevisiae (F707) was lower than it in S. cerevisiae (F514). 
Table 1. Proximate chemical composition of distilled yeast and baker's yeast strains

\begin{tabular}{|c|c|c|c|c|c|c|c|}
\hline \multirow{2}{*}{ Yeast strains } & \multicolumn{5}{|c|}{ Proximate chemical composition \% (Dry weight basis) } \\
\cline { 2 - 8 } & Moisture & Dry matter & Protein & Ash & Fat & $\begin{array}{c}\text { Total } \\
\text { carbohydrates }\end{array}$ & Trehalose \\
\hline S. cerevisiae (F514) & $76.61^{\mathrm{a}}$ & $23.39^{\mathrm{b}}$ & $46.63^{\mathrm{b}}$ & $7.91^{\mathrm{a}}$ & $3.77^{\mathrm{b}}$ & $41.68^{\mathrm{a}}$ & $6.27^{\mathrm{b}}$ \\
S. cerevisiae (F707) & $75.33^{\mathrm{b}}$ & $24.67^{\mathrm{a}}$ & $50.22^{\mathrm{a}}$ & $6.8^{\mathrm{b}}$ & $5.1^{\mathrm{a}}$ & $37.88^{\mathrm{b}}$ & $7.03^{\mathrm{a}}$ \\
\hline
\end{tabular}

* Means in the same column followed by different letters are significantly different $(P \leq 0.05)$.

${ }^{*}$ Results are presented as means for triplicate analyses.

These results are in accordance with the general characteristics of fresh baker's yeast prepared by the technical committee of COFALEC, (2012). Trehalose levels found in laboratory strains grown in batch culture are at most 4 to $5 \%$ of the dry weight (Van Dijck et al 1995).

\section{Fermenting power of distilled yeast and baker's yeast strains}

Results in Fig. (1) show the fermenting power in flour dough fermented by $S$. cerevisiae (F514) and $S$. cerevisiae (F707) strains and there is no significant difference between the two strains. The obtained results are in agreement with (Ma'aruf et al 2011).

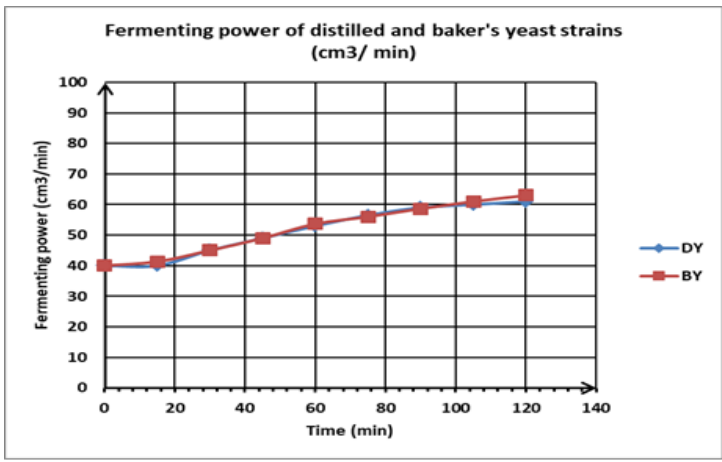

Fig. 1. The fermenting power of distilled and baker's yeast strains

*(DY) distilled yeast and (BY) baker's yeast
Proximate chemical composition of prepared pan bread samples

The proximate chemical composition of prepared pan bread produced by using $S$. cerevisiae (F514), S. cerevisiae (F707) and the mix between $S$. cerevisiae (F514) and commercial baker's yeast (CBY) with $1: 1(\mathrm{w} / \mathrm{w})$ ratio is presented in Table (2). No significant differences $(P \leq 0.05)$ between all treatments in crude protein, fat, fiber and total carbohydrates contents of pan bread by using S. cerevisiae (F514), S. cerevisiae (F707) and the mix between $S$. cerevisiae (F514) and commercial baker's yeast except in dry matter and ash contents. Pan bread produced by using $S$. cerevisiae (F514) recorded the highest ash content and this could be referred to $S$. cerevisiae (F514) has higher ash content than $S$. cerevisiae (F707). Pan bread produced by using the mix of $S$. cerevisiae (F514) and CBY recorded the lowest dry matter content.

\section{Physical measurements of prepared pan bread samples}

Physical measurements of prepared pan bread samples produced by using $S$. cerevisiae (F514), $S$. cerevisiae (F707) and the mix of $S$. cerevisiae (F514) and commercial baker's yeast with 1:1 $(\mathrm{w} / \mathrm{w})$ ratio were determined and the results are shown in Table (3). The obtained results revealed that pan bread produced by using the mix of $S$. cerevisiae (F514) and CBY with 1:1 ratio is the best treatment, it recorded the highest volume and specific volume being $\left(560 \mathrm{~cm}^{3}\right.$ and 4.06$)$, followed 

distilled biomass

Table 2. Proximate chemical composition of prepared pan bread samples

\begin{tabular}{|c|c|c|c|}
\hline \multirow{2}{*}{$\begin{array}{c}\text { Proximate chemical } \\
\text { composition \% }\end{array}$} & \multicolumn{3}{|c|}{ Pan bread samples produced by using } \\
\cline { 2 - 4 } (Dry weight basic) & $\begin{array}{c}\text { S. cerevisiae } \\
\text { (F514) }\end{array}$ & $\begin{array}{c}\text { S. cerevisiae } \\
\text { (F707) }\end{array}$ & $\begin{array}{c}\text { S. cerevisiae (F514) and } \\
\text { CBY (1:1) ratio }\end{array}$ \\
\hline Moisture & $37.25^{\mathrm{b}}$ & $37.35^{\mathrm{b}}$ & $37.96^{\mathrm{a}}$ \\
Dry matter & $62.75^{\mathrm{a}}$ & $62.65^{\mathrm{a}}$ & $62.04^{\mathrm{b}}$ \\
Protein & $12.26^{\mathrm{a}}$ & $12.26^{\mathrm{a}}$ & $12.1^{\mathrm{a}}$ \\
Fat & $3.91^{\mathrm{a}}$ & $4.12^{\mathrm{a}}$ & $4.41^{\mathrm{a}}$ \\
Ash & $1.93^{\mathrm{a}}$ & $1.62^{\mathrm{b}}$ & $1.45^{\mathrm{b}}$ \\
Crude fiber & $0.13^{\mathrm{a}}$ & $0.24^{\mathrm{a}}$ & $0.19^{\mathrm{a}}$ \\
Carbohydrates & $45.45^{\mathrm{a}}$ & $44.44^{\mathrm{a}}$ & $43.69^{\mathrm{a}}$ \\
\hline
\end{tabular}

* Means in the same column followed by different letters are significantly different $(P \leq 0.05)$.

* Results are presented as means for triplicate analyses.

* CBY: Commercial Baker's yeast

Table 3. Physical measurements of prepared pan bread samples

\begin{tabular}{|c|c|c|c|}
\hline \multirow{2}{*}{ Treatments } & \multicolumn{3}{|c|}{ Physical measurements of pan bread } \\
\cline { 2 - 4 } & Weight (g) & Volume $\left(\mathrm{cm}^{3}\right)$ & Specific volume $\left(\mathrm{cm}^{3} / \mathbf{g}\right)$ \\
\hline S. cerevisiae (F514) & $144.00^{\mathrm{a}}$ & $380.00^{\mathrm{c}}$ & $2.64^{\mathrm{C}}$ \\
S. cerevisiae (F707) & $139.75^{\mathrm{b}}$ & $447.50^{\mathrm{b}}$ & $3.20^{\mathrm{b}}$ \\
S. cerevisiae (F514) and CBY (1:1) & $138.00^{\mathrm{b}}$ & $560.00^{\mathrm{a}}$ & $4.06^{\mathrm{a}}$ \\
\hline
\end{tabular}

* Means in the same column followed by different letters are significantly different $(P \leq 0.05)$.

* Results are presented as means for triplicate analyses.

${ }^{*} \mathrm{CBY}$ : Commercial Baker's yeast

by using $S$. cerevisiae (F707) which recorded $\left(447.5 \mathrm{~cm}^{3}\right.$ and 3.20$)$, as well as using $S$. cerevisiae (F514) which recorded $\left(380 \mathrm{~cm}^{3}\right.$ and 2.64; respectively). Results could be referred to commercial baker's yeast and $S$. cerevisiae (F707) have higher fermenting power capacity than $S$. cerevisiae (F514). The difference in loaf volume, as well as specific loaf volume of pan bread samples could be referred to the variation in ability to retain carbon dioxide formed during the fermentation period (Abdel Rahman, 2015). The results are in accordance with Seleem and Mohamed (2014) and Ibrahim (2011).
Sensory evaluation of prepared pan bread samples

It could be observed from the results in Table (4) that pan bread samples prepared by using a mix of $S$. cerevisiae (F514) and CBY with 1:1 ratio had the highest scores in characteristics of crumb texture, taste characteristics and total acceptability (14.13, 18.5 and 92; respectively) followed by those produced by $S$. cerevisiae (F707) (13.25, 17.5 and 87.63; respectively), whereas minimum scores were given to samples produced by $S$. cerevisiae (F514) $(12.25,16.25$ and 81.13; respectively). These results could be referred to comer- 
cial baker's yeast and $S$. cerevisiae (F707) have higher fermenting power capacity and produced more gas and flavor compounds during fermentation than $S$. cerevisiae (F514). No significant differences observed $(P \leq 0.05)$ between all treatments samples in aroma, mouth feel, crumb color, crust color, break and sheared and symmetry of shape.
These results are in agreement with those obtained by Mohammad (2010), who reported that the sensory characteristics of pan bread (control) were 4.6, 9.1, 8.6, 13.8, 9.2, 18.4, 19.3 and 9.1 for symmetry of shape, crust color, break and shred, crumb texture, crumb color, aroma, taste and mouth feel, respectively.

Table 4. Organoleptic characteristics of prepared pan bread samples

\begin{tabular}{|c|c|c|c|}
\hline \multirow{2}{*}{$\begin{array}{c}\text { Score of organoleptic } \\
\text { characteristics }\end{array}$} & \multicolumn{3}{|c|}{ Treatments } \\
\cline { 2 - 4 } & S. cerevisiae (F514) & S. cerevisiae (F707) & $\begin{array}{c}\text { S. cerevisiae (F514) } \\
\text { and CBY (1:1) }\end{array}$ \\
\hline Taste (20) & $16.25^{\mathrm{b}}$ & $17.50^{\mathrm{a}}$ & $18.50^{\mathrm{a}}$ \\
Aroma (20) & $17.00^{\mathrm{a}}$ & $17.25^{\mathrm{a}}$ & $18.25^{\mathrm{a}}$ \\
Mouth feel (10) & $7.50^{\mathrm{a}}$ & $8.00^{\mathrm{a}}$ & $8.63^{\mathrm{a}}$ \\
Crumb texture (15) & $12.25^{\mathrm{b}}$ & $13.25^{\mathrm{b}}$ & $14.13^{\mathrm{a}}$ \\
Crumb color (10) & $8.00^{\mathrm{b}}$ & $8.63^{\mathrm{b}}$ & $8.88^{\mathrm{a}}$ \\
Crust color (10) & $8.38^{\mathrm{a}}$ & $8.75^{\mathrm{a}}$ & $8.88^{\mathrm{a}}$ \\
Break\& sheared (10) & $8.00^{\mathrm{a}}$ & $8.50^{\mathrm{a}}$ & $8.88^{\mathrm{a}}$ \\
Symmetry shape (5) & $3.75^{\mathrm{a}}$ & $4.50^{\mathrm{a}}$ & $4.63^{\mathrm{a}}$ \\
\hline Total score (100) & $81.13^{\mathrm{b}}$ & $87.63^{\mathrm{a}}$ & $92.00^{\mathrm{a}}$ \\
\hline
\end{tabular}

* Means in the same column followed by different letters are significantly different $(P \leq 0.05)$.

${ }^{*}$ Results are presented as means for triplicate analyses.

* CBY: Commercial Baker's yeast

\section{Freshness of prepared pan bread samples}

There was a significant gradual decrease in swelling power of pan bread samples (Table 5). Pan bread produced by using a mix of $S$. cerevisiae (F514) and CBY with 1:1 ratio significantly recorded the highest freshness compared to the other two treatments during storage at room temperature $25 \pm 2^{\circ} \mathrm{C}$ for $0,24,48$ and $72 \mathrm{~h}$.

In addition, staling rate increased significantly during storage intervals and the highest freshness loss in all samples was after $72 \mathrm{~h}$. The highest freshness value after $72 \mathrm{~h}$ was recorded by samples produced by using a mix of $S$. cerevisiae
(F514) and CBY with 1:1 ratio (148.61\%) compared to $122.36 \%$ and $121.53 \%$ for samples produced by using $S$. cerevisiae (F514) and S. cerevisiae (F707); respectively. The results in agreement with Erazo-Castrejon et al (2001), who found that the bread firmness was increased by increasing the storage period, and also in accordance with Hug-Iten et al (1999) who reported that starch retrogradation occurs during the cooling period after baking, in which the amylose and amylopectin chains aggregate forming crystalline double helices stabilized by hydrogen bonds, leading to bread hardening. 

distilled biomass

Table 5. Alkaline water retention capacity (\%) of prepared pan bread samples during storage at room temperature $25 \pm 2^{\circ} \mathrm{C}$

\begin{tabular}{|c|c|c|c|}
\hline \multirow{2}{*}{ Storage period (h) } & \multicolumn{3}{|c|}{ Treatments } \\
\cline { 2 - 4 } & S. cerevisiae (F514) & S. cerevisiae (F707) & $\begin{array}{c}\text { S. cerevisiae (F514) } \\
\text { and CBY (1:1) }\end{array}$ \\
\hline Zero & $209.72^{\mathrm{Ba}}$ & $212.29^{\mathrm{Ba}}$ & $221.58^{\mathrm{Aa}}$ \\
$\mathbf{2 4}$ & $155.72^{\mathrm{Bb}}$ & $151.67^{\mathrm{Bb}}$ & $152.27^{\mathrm{Ab}}$ \\
$\mathbf{4 8}$ & $141.4^{\mathrm{Bc}}$ & $140.73^{\mathrm{Bc}}$ & $136.18^{\mathrm{Ac}}$ \\
$\mathbf{7 2}$ & $121.53^{\mathrm{Bd}}$ & $122.36^{\mathrm{Bd}}$ & $148.61^{\mathrm{Ad}}$ \\
\hline
\end{tabular}

${ }^{*}$ Means in the same column followed by different letters are significantly different $(P \leq 0.05)$.

* Results are presented as means for triplicate analyses.

* Capital letter for the effect of treatment and small letter for the effect of storage period.

* CBY: Commercial Baker's yeast

Color properties of prepared pan bread samples

The color characteristics $\left(L^{*}, a^{*}, b^{*}\right.$ and $\Delta E$ ) of pan bread crust and crumb are given in Tables (6) and (7). Redness $\left(a^{*}\right)$ values recorded by crust of pan bread samples were significantly different. The crust of pan bread produced by using $S$. cerevisiae (F514) recorded the lowest $a^{*}$ while, samples produced by using $S$. cerevisiae (F707) recorded the highest value. The results are with accordance with Gomez et al 2003, who reported that crust characteristic is known to be associated with Maillard reaction, thus containing more protein can increase the Maillard reaction and browner color in the crust of bread. The results probably due to higher protein content of $S$. cerevisiae (F707) compared to $S$. cerevisiae (F514).

The results are also in accordance with El-Dash and Johnson, (1970) who reported that yeast is a potential source of primary amino groups in dough. When yeast was added to dough, approximately a $400 \%$ increase in total free amino acids was observed. Although fermentation reduced the dough content of free amino acids, about twice as much remained in the dough after fermentation as was originally present in flour. The marked decrease in free amino acid content in the bread crust demonstrated their importance in the non enzymatic browning reaction during baking. The concentration of intermediate compounds and brown melanoidin pigments produced by the non enzymatic browning reaction was considerably increased in bread crust as a result of fermentation.

Significant differences could be observed between pan bread samples in the yellowness $\left(b^{*}\right)$. The crust of pan bread produced by using $S$. cerevisiae (F707) recorded the highest $\left(b^{*}\right)$ followed by $S$. cerevisiae (F514) and mix of $S$. cerevisiae (F514) and CBY with 1:1 ratio (29.31, 28.62 and 27.08; respectively).

Total color differences $(\Delta E)$ between the crusts of tested pan bread samples are presented in Table (6). It was found that $(\Delta E)$ value in pan bread samples produced by $S$. cerevisiae (F514) was higher than in S. cerevisiae (F707) samples.

Pan bread samples produced by using mix of S. cerevisiae (F514) and CBY with 1:1 ratio recorded the highest lightness $\left(L^{*}\right)$ in crust, followed by $S$. cerevisiae (F707) and $S$. cerevisiae (F514) samples. The lowest $\left(L^{*}\right)$ in crumb was recorded by samples produced by using $S$. cerevisiae (F514) and the highest value was by samples produced by using $S$. cerevisiae (F707) followed by samples produced by using mix of $S$. cerevisiae (F514) and CBY with 1:1 ratio. 
Table 6. Crust color attributes of prepared pan bread samples

\begin{tabular}{|c|c|c|c|c|c|c|c|}
\hline \multirow{2}{*}{ Treatments } & \multicolumn{7}{|c|}{ color attributes of pan bread } \\
\cline { 2 - 8 } & $\boldsymbol{L}^{*}$ & $\boldsymbol{a}^{*}$ & $\boldsymbol{b}^{*}$ & $\boldsymbol{a} / \boldsymbol{b}$ & Saturation & Hue & $\Delta \boldsymbol{E}$ \\
\hline S. cerevisiae (F514) & $54.13^{\mathrm{a}}$ & $16.3^{\mathrm{c}}$ & $27.08^{\mathrm{c}}$ & $1.67^{\mathrm{b}}$ & $31.61^{\mathrm{c}}$ & $58.95^{\mathrm{b}}$ & $2.88^{\mathrm{a}}$ \\
S. cerevisiae (F707) & $53.34^{\mathrm{a}}$ & $18.17^{\mathrm{a}}$ & $29.31^{\mathrm{a}}$ & $1.61^{\mathrm{c}}$ & $34.48^{\mathrm{a}}$ & $58.2^{\mathrm{c}}$ & $2.32^{\mathrm{b}}$ \\
S. cerevisiae (F514) and CBY mix & $51.76^{\mathrm{b}}$ & $16.64^{\mathrm{b}}$ & $28.62^{\mathrm{b}}$ & $1.72^{\mathrm{a}}$ & $33.11^{\mathrm{b}}$ & $59.83^{\mathrm{a}}$ & \\
\hline
\end{tabular}

Where: $\left(\mathrm{L}^{*}\right)$ Lightness; $\left(\mathrm{a}^{*}\right)$ redness; $\left(\mathrm{b}^{*}\right)$ yellowness and $(\Delta \mathrm{E})$ color difference.

${ }^{*}$ Means in the same column followed by different letters are significantly different $(P \leq 0.05)$.

* Results are presented as means for triplicate analyses.

* CBY: Commercial Baker's yeast

Table 7. Crumb color attributes of prepared pan bread samples

\begin{tabular}{|c|c|c|c|c|c|c|c|}
\hline \multirow{2}{*}{ Treatments } & \multicolumn{7}{|c|}{ color attributes of pan bread } \\
\cline { 2 - 8 } & $\boldsymbol{L}^{*}$ & $\boldsymbol{a}^{*}$ & $\boldsymbol{b}^{\star}$ & $\mathbf{a} / \mathbf{b}$ & Saturation & Hue & $\Delta \boldsymbol{E}$ \\
\hline S. cerevisiae (F514) & $72.95^{\mathrm{c}}$ & $3.05^{\mathrm{a}}$ & $22.97^{\mathrm{a}}$ & $7.53^{\mathrm{c}}$ & $23.17^{\mathrm{a}}$ & $82.44^{\mathrm{c}}$ & $1.96^{\mathrm{b}}$ \\
S. cerevisiae (F707) & $75.68^{\mathrm{a}}$ & $1.93^{\mathrm{b}}$ & $22.97^{\mathrm{a}}$ & $11.92^{\mathrm{a}}$ & $23.05^{\mathrm{b}}$ & $85.21^{\mathrm{a}}$ & $2.02^{\mathrm{a}}$ \\
S. cerevisiae (F514) and CBY mix & $74.06^{\mathrm{b}}$ & $1.97^{\mathrm{b}}$ & $21.78^{\mathrm{b}}$ & $11.04^{\mathrm{b}}$ & $21.87^{\mathrm{c}}$ & $84.82^{\mathrm{b}}$ & \\
\hline
\end{tabular}

Where: $\left(\mathrm{L}^{*}\right)$ Lightness; $\left(\mathrm{a}^{*}\right)$ redness; $\left(\mathrm{b}^{*}\right)$ yellowness and $(\Delta \mathrm{E})$ color difference.

${ }^{*}$ Means in the same column followed by different letters are significantly different $(P \leq 0.05)$.

* Results are presented as means for triplicate analyses.

* CBY: Commercial Baker's yeast

The results are in agreement with Ma'aruf et al (2011) who reported that the crust color of bread fermented by SMK9, SRB11 and SS12 S. cerevisiae strains, as well as commercial baker's yeast were considered darker than SKS2 and SM16 (with lower $L^{*}$ value). This could be due to progressive reduction of sugar during fermentation releasing carbon dioxide and generating energy, thus impaired Maillard Reaction.
Texture profile analysis of prepared pan bread samples

Texture profile analysis (hardness, cohesiveness, springiness, gumminess, chewiness) of pan bread produced by using $S$. cerevisiae (F514), S. cerevisiae (F707) and mix of $S$. cerevisiae (F514) and CBY with 1:1 ratio are shown in Table (8) and Fig. (1). It could be observed that the samples produced by treatment 3 had the lowest value of hardness $(6.685 \mathrm{~N})$, followed by treatment 2 (15.02 $\mathrm{N})$, as well as treatment $1(16.86 \mathrm{~N})$. 

distilled biomass

Table 8. Texture profile parameters of prepared pan bread samples

\begin{tabular}{|c|c|c|c|c|c|}
\hline \multirow{2}{*}{ Treatments } & \multicolumn{5}{|c|}{ Texture profile parameters of pan bread } \\
\cline { 2 - 6 } & $\begin{array}{c}\text { Hardness } \\
\mathbf{N}\end{array}$ & $\begin{array}{c}\text { Springiness } \\
\mathbf{M m}\end{array}$ & Cohesiveness & $\begin{array}{c}\text { Chewiness } \\
\mathbf{J}\end{array}$ & $\begin{array}{c}\text { Gumminess } \\
\mathbf{N}\end{array}$ \\
\hline S. cerevisiae (F514) & 16.86 & 0.69 & 18.96 & 11.98 & 227.10 \\
S. cerevisiae (F707) & 15.02 & 0.71 & 19.43 & 10.94 & 212.40 \\
S. cerevisiae (F514) and & 6.685 & 0.72 & 19.68 & 4.97 & 97.80 \\
CBY mix & &
\end{tabular}

${ }^{*}$ CBY: Commercial Baker's yeast

The results are also in accordance with Wanga et al (2002) and Yamsaengsung et al (2010), who stated that the increase loaf volume is directly related to the decrease hardness values.

The results revealed that chewiness and gumminess values were increased by increasing the hardness of pan bread. Therefore, the chewiness and gumminess values had a similar trend of hardness. These results are in agreement with Ibrahim, (2011), who reported that both gumminess and chewiness parameters are dependent on hardness. Chewiness is one of the texture parameters easily correlated with sensory analyses (Gomez et al 2007 and Esteller et al 2004).

The results indicate that pan bread samples produced by using mix of $S$. cerevisiae (F514) and CBY with 1:1 ratio which rated higher sensory characteristics (Table --), recorded the lowest values of chewiness $(4.97 \mathrm{~J})$. These results are in agreement with Boz and Karaoglu, (2013), who reported that the chewiness values of bread crumb had a negative correlation with sensory properties. Also Ibrahim (2011) reported that the cohesiveness determines the internal resistance of food structure. In general, high cohesiveness is desirable in bread because bread can form a bolus, rather than disintegrate, during mastication (Onyango et al 2010). The highest value in this respect was recorded by samples produced by using mix of $S$. cerevisiae (F514) and CBY with 1:1 ratio (19.68), followed by $S$. cerevisiae (F707) (18.96) and S. cerevisiae (F514) (19.43).
With regard to springiness of pan bread samples, the results in (Table 8) indicate that pan bread produced by using $\mathrm{mix}$ of $S$. cerevisiae (F514) and CBY with 1:1 ratio had the highest springiness $(0.72 \mathrm{~mm})$. Meanwhile, pan bread produced by $S$. cerevisiae (F514) had the lowest values of springiness $(0.69 \mathrm{~mm})$. The results reveal also that the cohesiveness and springiness showed similar trends. Springiness is a measurement of how much the bread crumb springs back after being compressed once and it can be defined as the elasticity of the bread crumb (Karaoglu, et al 2008 and Tian et al 2009).

Correlation coefficients between physical and sensory properties of prepared pan bread

Correlation coefficients between physical and sensory properties of pan bread produced by using S. cerevisiae (F514), S. cerevisiae (F707) and a mix of $S$. cerevisiae (F514) and commercial baker's yeast with 1:1 are shown in Table (9).

Positive significant correlations were found between specific volume and aroma, crumb texture, symmetry shape and the total acceptability being $0.866^{*}, 0.883^{*}, 0.902^{*}$ and $0.943^{* *}$; respectively. Positive significant correlations also were found between volume and aroma, crumb texture, symmetry shape and total acceptability being $0.877^{\star}, 0.886^{\star}, 0.914^{\star}$ and $0.946^{\star *}$; respectively). 

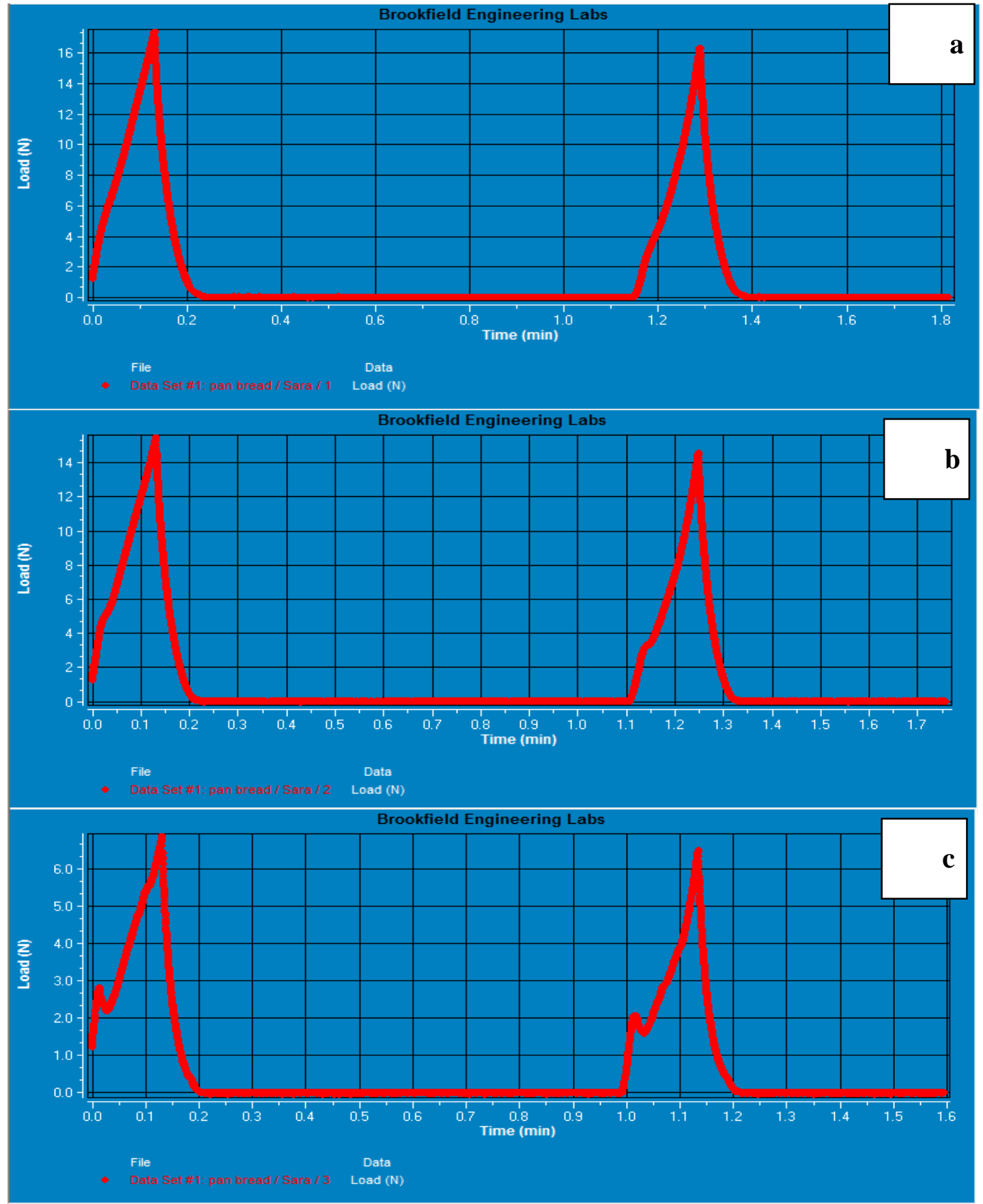

Fig. 2. Texture profiles of produced pan bread samples

Where: (a) Pan bread produced by S. cerevisiae (F707); (b) Pan bread produced by S. cerevisiae (F514) and (c) Pan bread produced by the mix of $S$. cerevisiae (F514) and CBY. 

distilled biomass

Table 9. Correlation coefficients between physical and sensory properties of pan bread

\begin{tabular}{|c|c|c|c|c|c|c|c|c|c|c|}
\hline & Treatment & Taste & Aroma & $\begin{array}{c}\text { Mouth } \\
\text { feel }\end{array}$ & $\begin{array}{l}\text { Crumb } \\
\text { texture }\end{array}$ & $\begin{array}{c}\text { Break } \\
\text { and } \\
\text { sheard }\end{array}$ & $\begin{array}{l}\text { Symmetry } \\
\text { shape }\end{array}$ & Weight & Volume & $\begin{array}{l}\text { Specific } \\
\text { volume }\end{array}$ \\
\hline $\begin{array}{l}\text { Treatment } \\
\text { Taste } \\
\text { Aroma } \\
\text { Mouth feel } \\
\text { Crumb } \\
\text { texture } \\
\text { Break } \\
\text { and sheared } \\
\text { Symmetry } \\
\text { shape } \\
\text { Total } \\
\text { acceptability } \\
\text { Weight } \\
\text { Volume } \\
\text { Specific } \\
\text { volume }\end{array}$ & 1 & $.637^{* *}$ & $\begin{array}{l}.318 \\
.576^{* *}\end{array}$ & $\begin{array}{l}.343 \\
.423^{*} \\
.668^{* *}\end{array}$ & $\begin{array}{l}.531^{* *} \\
.419^{*} \\
.692^{* *} \\
.708^{* *}\end{array}$ & $\begin{array}{l}.343 \\
.178 \\
.536^{* *} \\
.645^{* *} \\
.797^{* *}\end{array}$ & $\begin{array}{l}.365 \\
.269 \\
.384 \\
.468^{*} \\
.547^{* *} \\
.483^{*}\end{array}$ & $\begin{array}{c}.946-^{* *} \\
-.620 \\
-.676 \\
-.677 \\
-.848-^{*} \\
-.747 \\
-.706 \\
-.870-{ }^{*}\end{array}$ & $\begin{array}{l}.974^{* *} \\
.660 \\
.877^{*} \\
.779 \\
.886^{*} \\
.700 \\
.914^{*} \\
.946^{* *} \\
-.9300^{* *}\end{array}$ & $\begin{array}{l}.974^{* *} \\
.658 \\
.866^{*} \\
.770 \\
.883^{*} \\
.709 \\
.902^{*} \\
.943^{* *} \\
-.940-^{* *} \\
1.000^{* *}\end{array}$ \\
\hline
\end{tabular}

Correlation coefficients between texture and physical properties of prepared pan bread

Correlation coefficients between texture and physical properties of pan bread produced by using S. cerevisiae (F514), S. cerevisiae (F707) and a mix of $S$. cerevisiae (F514) and commercial baker's yeast with 1:1 are shown in Table (10).
Positive significant correlation was found between cohesiveness and springiness $\left(1.000^{* *}\right)$, hardness and gumminess $\left(0.999^{*}\right)$, hardness and chewiness $\left(0.998^{*}\right)$. Negative non-significant correlation was found between specific volume and hardness, gumminess and chewiness being $0.990,-0.985$ and -0.979 ; respectively.

Table 10. Correlation coefficients between texture and physical properties of pan bread

\begin{tabular}{|c|c|c|c|c|c|c|c|c|c|}
\hline & Treatment & $\begin{array}{l}\text { Hard- } \\
\text { ness }\end{array}$ & $\begin{array}{l}\text { Cohe- } \\
\text { sive- } \\
\text { ness }\end{array}$ & $\begin{array}{l}\text { Springi- } \\
\text { ness }\end{array}$ & $\begin{array}{c}\text { Gummi- } \\
\text { ness }\end{array}$ & $\begin{array}{l}\text { Chewi- } \\
\text { ness }\end{array}$ & Weight & Volume & $\begin{array}{l}\text { Specific } \\
\text { volume }\end{array}$ \\
\hline Treatment & 1 & -.938 & .982 & .985 & -.927 & -.913 & $-.946-{ }^{* *}$ & $.974^{* *}$ & $.974^{* *}$ \\
\hline Hardness & & & -.856 & -.864 & $.999^{*}$ & $.998^{*}$ & .907 & -.992 & -.990 \\
\hline Cohesiveness & & & & $1.000^{* *}$ & -.839 & -.820 & -.994 & .913 & .920 \\
\hline Springiness & & & & & -.847 & -.829 & -.996 & .919 & .926 \\
\hline Gumminess & & & & & & $.999^{*}$ & .892 & -.988 & -.985 \\
\hline Chewiness & & & & & & & .877 & -.982 & -.979 \\
\hline Weight & & & & & & & & $-.930-{ }^{* *}$ & $-.940-{ }^{* *}$ \\
\hline Volume & & & & & & & & & $1.000^{* *}$ \\
\hline $\begin{array}{l}\text { Specific } \\
\text { volume }\end{array}$ & & & & & & & & & \\
\hline
\end{tabular}

${ }^{*} \boldsymbol{P} \leq 0.05$.

${ }^{* *} \boldsymbol{P} \leq 0.01$. 


\section{Conclusion}

The results of the current study show that the chemical properties and fermenting capacity of the distilled yeast strain became near to the properties of the reference baker's yeast strain and when the two strains were applied in pan bread making by using distilled yeast strain, the reference baker's yeast and a mix of distilled yeast strain and commercial baker's yeast with 1:1 ratio, noticed that the mix of distilled yeast strain and commercial baker's yeast with $1: 1$ ratio is the best treatment.

\section{ACKNOWLEDGMENT}

The authors would like to acknowledge Dr. Mohammed Fadel Soliman, Researcher Prof. of Genetic Engineering, Department of Microbial Chemistry, National Research Center for his continuous supported, valuable help in this work and for the extremely good research and aid facilities.

\section{REFERENCES}

A.A.C.C. 2009. International Approved Methods of Analysis $11^{\text {th }}$ Ed. American Association of Cereal Chemists, INC. st., Paul, Minnesota, USA.

Abdel Rahman, G.N. 2015. Production of baker's yeast from Saccharomyces cerevisiae strains resistant to some contaminants. Ph.D. Thesis, Food Technology Dep. Fac. Agric., Cairo Univ., Giza, Egypt. pp. 47-148.

A.O.A.C. 2012. Official Methods of Analysis of the Association of Official Analytical Chemistry (A.O.A.C.) International, $19^{\text {th }}$ ed., Gaithersburg, Maryland, USA.

Birch, A.N., Petersen, M.A., and Hansen, A.S. 2013. The aroma profile of wheat bread crumb influenced by yeast concentration and fermentation temperature. LWT - Food Science and Technology, 50, 480-488.

Borzani, W. 2004. Measurement of the gassing power of bakers' yeast: correlation between the dough volume and the incubation time. Brazilian Archives of Biology and Technology, 47(2), 213-217.

Bothast, R.J. and Schlicher, M.A. 2005. Biotechnological processes for conversion of corn into ethanol. Applied Microbiology and Biotechnology, 67(1), 19-25.
Boz, H. and Karaoglu, M.M. 2013. Improving the quality of whole wheat bread by using various plant origin materials. Czech J. Food Sci., 31(5), 457-466.

COFALEC. 2012. Confederation of European Yeast producers. The technical committee, pp. 1-8, Paris, France

El-Dash, A.A. and Johnson, J.A. 1970. Influence of yeast fermentation and baking on the content of free amino acids and primary amino groups and their effect on bread aroma stimuli. Cereal Chemistry, 47, 247-258.

Erazo-Castrejon, S.V., Doehlert, D.C. and AppoIonia, B.L. 2001. Application of oat oil in bread making. Cereal Chemistry, 78, 243-248.

Esteller, M.S., Amaral, R.L. and Lannes, S.C. 2004. Effect of sugar and fat replacers on the texture of baked goods. J. Texture Studies, 35, 383-393.

Faheid, S.M.M., Fadel, M. and Makhlouf, S.K.M. 1997. Improvement of fodder yeast for employment as baker's yeast in balady bread making. Egyptian J. of Food Sci., 25(2-3), 199-212.

Fatma, Abd El-Zaher, Shams El-Din, M.H.A. and Fadel, M. 2012. Perspectives for appropriating distilled yeast to be used in bakery. International J. Academic Research, 4(4), 11-16.

Finney, K.F. 1984. An optimized, straight-dough bread-making method after 44 years. Cereal Chemistry, 61, 20-27.

Frasse, P., Lambert, S., Levesque, C., Melcion, D., Richard-Molard, D. and Chiron, H. 1992. The influence of fermentation on volatile compounds in French bread crumb. Food Science and Technology, Lebensmittel-Wissenschaft \& Technologie, 25, 66-70.

Gomez, M., Ronda, F., Caballero, P.A., Blanco, C.A. and Rosell, C.M. 2007. Functionality of different hydrocolloids on the quality and shelflife of yellow layer cakes. Food Hydrocolloids, 21, 167-173.

Gomez, M., Ronda, F., Blanco, C., Caballero, P. and Apesteguia, A. 2003. Effect of dietary fiber on dough rheology and bread quality. European Food Research Technology, 216, 5156.

https://www.siicegypt.com/factories.htm

Hug-Iten, S., Handschin, S., Conde-Petit, B. and Escher, F. 1999. Changes in starch microstructure on baking and staling of wheat bread. Food Sci. and Technology, 32, 255-260.

Hunter, R.S. 1975. Uniform color scales. In: "The measurement of appearance". pp. 102-132. John Wiley \& Sons: New York, USA. 

distilled biomass

Ibrahim, M.A.K. 2011. Chemical and biological studies on some bakery products. Ph.D. Thesis, Food Sci. Dept. Fac. Agric., Moshtohor, Banha Univ., Egypt, 184 p.

Karaoglu, M.M., Kotancilar, H.G. and Gerçekaslan, K.E. 2008. The effect of parbaking and frozen storage time on the quality of cup cake. Int. J. of Food Sci. and Technology, 43, 1778-1785.

Kulp, K., Chung, H., Martinez-Anaya, M.A. and Doerry, W. 1985. Fermentation of water ferments and bread quality. Cereal Chemistry, $32,55-59$.

Ludwig, T.G. and Goldberg, H.J.V. 1956. The anthrone method for the determination of carbohydrates in foods and in oral rinsing. J. of Dental Research, 35(1), 90-94.

Ma'aruf, A.G., Asyikeen, Z.N., Sahilah, A.M. and Khan, A.M. 2011. Leavening Ability of Yeast Isolated from Different Local Fruits in Bakery Product. Sains Malaysiana 40(12), 1413-1419.

Mohammad, A.A. 2010. Low phenylalanine bread and pasta: production, improvement and evaluation. M.Sc. Thesis, Food Technology Dept. Fac. Agric., Cairo Univ., Egypt, 125 p.

Onyango, C., Mutungi, C., Unbehend, G., Meinolf, G. and Lindhauer, M.G. 2010. Rheological and baking characteristics of batter and bread prepared from pregelatinised cassava starch and sorghum and modified using microbial transglutaminase. J. of Food Engineering, 97, 465-470.

SAS 2008. System for Windows (Statistical Analysis System), Version 9.2. Cary, USA: SAS Institute Inc.

Schieberle, P. and Grosch, W. 1991. Potent odorants of the wheat bread crumb. Zeitschrift für Lebensmittel-Untersuchung und Forschung, 192, 130-135.
Seleem, H.A. and Mohamed Z.M. 2014. Influence of some medicinal and aromatic plants addition on pan bread quality. World J. of Dairy \& Food Sci., 9(2), 299-307.

Taylor, G.T. and Marsh, A.S. 1984. MYGP + copper, a medium that detects both Saccharomyces and non-Saccharomyces wild yeast in the presence of culture yeast. J. of Institute of Brewing, 90, 134-145.

Tian, Y.Q., Li, Y., Jin, Z.Y., Xu, X.M., Wang, J.P., Jiao, A.Q., Yu, B. and Talba, T. 2009. $\beta$ cyclodextrin ( $\beta-C D)$ : A new approach in bread staling. Thermochimica Acta, 489, 22-26.

Trevelyan, W.E. and Harrison, J.S. 1956. Studies on yeast metabolism:Yeast carbohydrate fractions. Separation from nucleic acid, analysis, and behaviour during anaerobic fermentation. Biochemical J., 63(1), 23-33.

Van Dijck, P., Colavizza, D., Smet, P. and Thevelein, J.M. 1995. Differential Importance of Trehalose in Stress Resistance in Fermenting and Nonfermenting Saccharomyces cerevisiae Cells. Application of Environmental Microbiology, 61(1), 109-115.

Wanga, J., Rosella, C.M. and Barbera, C.B. 2002. Effect of the addition of different fibres on wheat dough performance and bread quality. Food Chemistry, 79, 221-226.

Yamsaengsung, R., Schoenlechner, R. and Berghofer, E. 2010. The effects of chickpea on the functional properties of white and whole wheat bread. Int. J. of Food Sci. and Technology, 45, 610-620. 

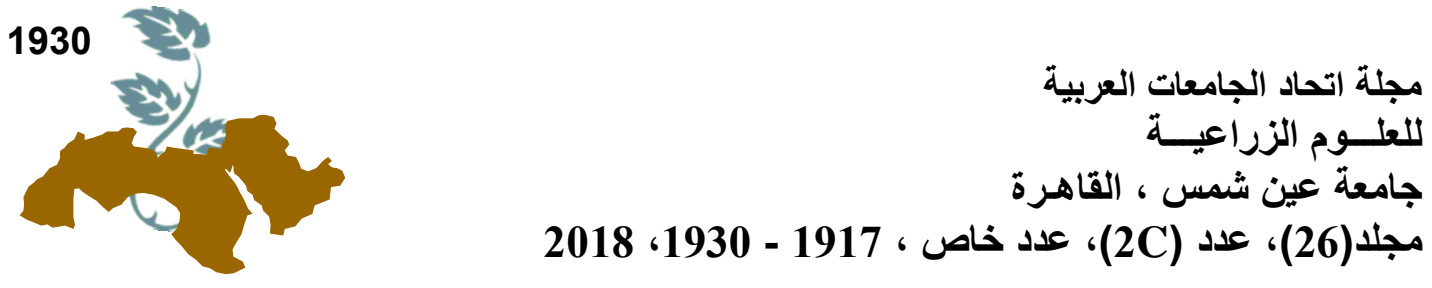

\section{تقييم جودة خبز القوالب المجز بإستخدام خميرة الخباز المتحصل عليها من تقطير المولاس}

[141]

$$
\begin{aligned}
& \text { سارة عيد أحمد سليمان } 1 \text { - السيد إبراهيم يوسف2 }{ }^{2} \text { - عبد الفتاح عبد الكريم عبد الفتاح² - } \\
& \text { محمد حامد شمس الدين } 1 \\
& \text { 1- قسم تكنولوجيا الأغذية - المركز القومى للبحوث - الدقى - الجيزة - مصر } \\
& \text { 2- قسم علوم الأغذية- كلية الزراعة- جامعة عين شمس - ص.ب. } 68 \text { حدائق شبرا } 11241 \text { - القاهرة- دصر }
\end{aligned}
$$

و 16.25 و 18.13 على التوالى). وكان هناك الت تتاقص تدريجى فى قدرة العينات على إحتجاز الماء الهاء

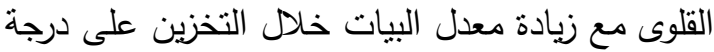

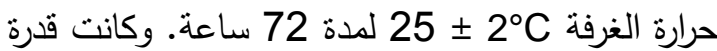
عبنات المعاملة رقم 3 على إحتجاز الماء القلوى بعد بعاء

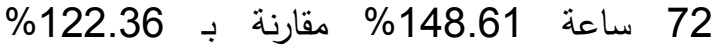
و121.53\% لعينات المعاملة رقم 1 والمعاملة رقم 2 على التوالى. وقد سجلت عينات المعاملة رقم 2 أعلى الكى

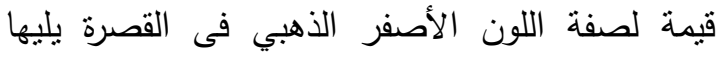
المعاملة رقم1 والمعاملة رقم 3. أما فى اللبابة، سجلت الاصن عينات المعاملة رقم 1 أقل قيمة لصفة المقات اللون الأبيض، بينما سجلت عينات المعاملة رقم 2 أعلى قيمة ليلية لاليها عينات المعاملة رقم 3. وكانت أقل قيمة لصفة اعلى الصلابة سجلتها عينات المعاملـة رقم 3 (15.02 (6.685)

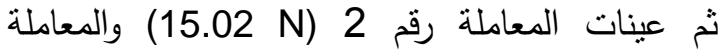
الأولى (16.86 N). وسجلت عينات المعاملة رقم 3 (15.02

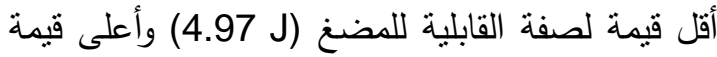

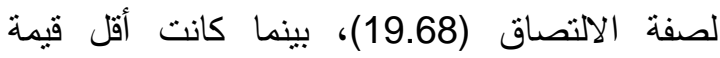

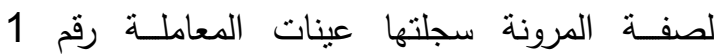
.(0.69 mm)
الكلمات الدالة: خميرة التقطير، خميرة الخباز، القوة التخميرية، خبز القوالب، الخواص الطبيعية، اللون، الفيرة التهات، الطزاجة

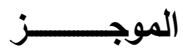

تم دراسة التركيب الكيماوى و الخصائص الطبيعية

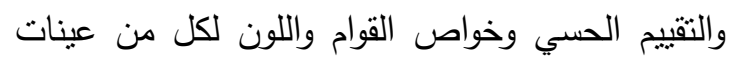
خبز القوالب التى تم إنتاجها بإستخدام المعاملة رقم 1) 1.

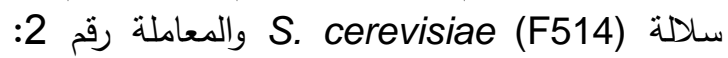
سلالة S. cerevisiae (F707) والمعاملة رقم 3: S. S. خليط من سلالة S. cerevisiae (F514) وخميرة الخباز التجارية بنسبة 1:1. وقد أظهرت النتائج وجود فروق معنوية بين عينات خبز القوالب فى محتواها من الرماد والمادة الجافة. سجلت عينات المعاملة رقم 3 رئر

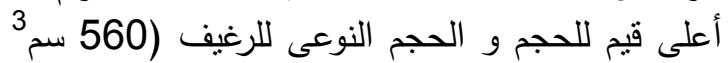

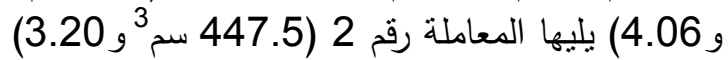

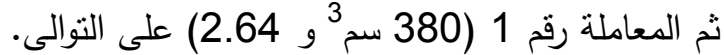

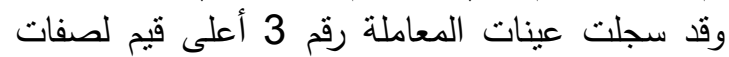
قوام اللبابة والطعم والقبول العام (14.13 و 18.5

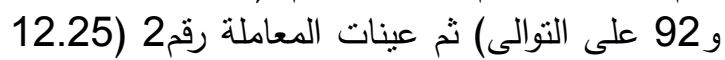

تحكيم: ا.د إبراهيم رزق سبد أحمد

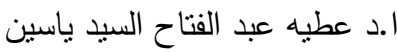

